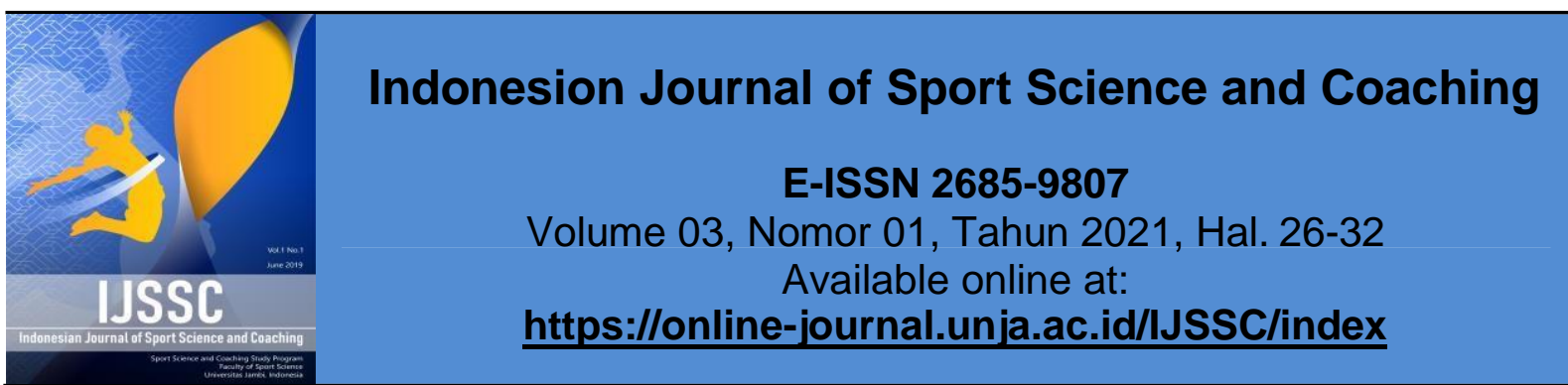

Research Article

OPEN ACCESS

\title{
Modifikasi Media Teknik Dassar Passing Bawah Permainan Bola Voli Melalui Video Tutorial Bagi Siswa SD Negeri 190 Tanjung Jabung Barat
}

\author{
(Efforts to Introduce Bridge Sports Through Video Tutorials \\ in West Tanjung Jabung Regency)
}

\begin{tabular}{|c|c|}
\hline \multicolumn{2}{|c|}{$\begin{array}{c}\text { Sukamto }^{1} \\
\text { Magister Teknologi Pendidikan, Universitas Jambi, Indonesia }{ }^{1} \\
\text { Coresspondence Author rsukamto351@gmail.com }\end{array}$} \\
\hline Informasi Artikel & $\begin{array}{l}\text { ABSTRACT } \\
\end{array}$ \\
\hline Submit: 19- $03-2021$ & $\begin{array}{l}\text { The use of instructional media during the COVID-19 period is } \\
\text { expected to make it easier for students to stay enthusiastic about } \\
\text { learning at home. Researchers innovate by changing the volleyball } \\
\text { that is commonly used for learning in school into a number of simple } \\
\text { tools that are more easily found by students. The purpose of this study } \\
\text { was to determine the media modification of the basic techniques of } \\
\text { passing under volleyball through video tutorials for elementary } \\
\text { students, as well as to find out students' understanding through video } \\
\text { tutorials of under passing techniques given by the teacher as learning } \\
\text { media. This research was conducted in } 190 \text { Tanjung Jabung Barat } \\
\text { Elementary School, Jambi Province, in the even semester of the } \\
2019 / 2020 \text { school year. By using descriptive qualitative research } \\
\text { methods. The subjects in this study were grade } 5 \text { students, amounting } \\
\text { to } 35 \text { students. The results of research conducted by researchers are } \\
\text { by uploading video tutorials that have been made to Youtube. } \\
\text { Researchers will begin to assess the effectiveness of the video based } \\
\text { on input from viewers of the video. In addition, researchers also made } \\
\text { a questionnaire / questionnaire containing opinions, and evaluations } \\
\text { of videos that have been uploaded. Based on the questionnaire, } \\
54.30 \% \text { of respondents said the video was effectively used as a } \\
\text { learning medium for elementary school students. } \\
\text { Keywords: Video Tutorials, Passing Down }\end{array}$ \\
\hline Penerbit & ABSTRAK \\
\hline $\begin{array}{l}\text { Jurusan Pendidikan } \\
\text { Olahraga dan Kepelatihan } \\
\text { FKIP Universitas Jambi } \\
\text { Jambi- Indonesia }\end{array}$ & $\begin{array}{l}\text { Penggunaan media pembelajaran di masa COVID-19 diharapkan dapat } \\
\text { memudahkan siswa untuk tetap bersemangat belajar di rumah. Peneliti } \\
\text { berinovasi dengan mengubah bola voli yang biasa digunakan untuk } \\
\text { pembelajaran di sekolah menjadi beberapa alat sederhana yang lebih } \\
\text { mudah ditemui oleh siswa. Tujuan penelitian ini adalah untuk } \\
\text { mengetahui modifikasi media teknik dasar passing bawah bola voli } \\
\text { melalui video tutorial untuk siswa SD, serta untuk mengetahui } \\
\text { pemahaman siswa melalui video tutorial teknik passing bawah yang } \\
\text { diberikan oleh guru sebagai media belajar. Penelitian ini dilaksanakan } \\
\text { di SD Negeri } 190 \text { Tanjung Jabung Barat Provinsi Jambi, pada semester } \\
\text { genap tahun ajaran } 2019 / 2020 \text {. Dengan menggunakan metode } \\
\text { penelitian deskriptif kualitatif. Subjek pada penelitian ini siswa kelas } 5 \\
\text { yang berjumlah } 35 \text { siswa. Hasil penelitian yang telah dilakukan oleh } \\
\text { peneliti adalah dengan mengunggah video tutorial yang telah dibuat ke }\end{array}$ \\
\hline
\end{tabular}


Youtube. Peneliti akan mulai menilai tentang keefektifan video berdasarkan dengan masukan dari penonton video tersebut. Selain itu, peneliti juga membuat angket/kuesioner yang berisikan tentang pendapat, dan evaluasi dari video yang sudah diunggah. Berdasarkan angket tersebut, sebanyak $54.30 \%$ responden mengatakan video tersebut efektif digunakan sebagai media pembelajaran untuk siswa Sekolah Dasar.

Kata Kunci : Video Tutorial, Passing Bawah

This Indonesian Journal of Sport Science and Coaching is licensed under a CC BY-NC-SA (Creative Commons Attribution-ShareAlike 4.0 International License)

\section{PENDAHULUAN}

Pendidikan jasmani merupakan media untuk mendorong perkembangan keterampilan motorik, kemampuan fisik, pengetahuan, penalaran, penghayatan nilai (sikap mental spiritual sosial), dan pembiasaan pola hidup sehat yang bermuara untuk merangsang pertumbuhan serta perkembangan yang seimbang.

Permainan bola voli merupakan salah satu materi yang disajikan dalam kurikulum pembelajaran pendidikan jasmani olahraga dan kesehatan di sekolah terutama di sekolah dasar dalam sub pembahasan permainan bola besar. Hal ini menunjukkan bahwa permainan bola voli dapat dijadikan sebagai alat untuk mencapai tujuan pendidikan. Karena permainan bola voli merupakan sarana untuk mendidik, nilai-nilai yang terkandung dalam permainan bola voli diharapkan dapat terbawa ke dalam perilaku sehari-hari. Nilai-nilai itu antara lain pada hidup sehat, disiplin, kerjasama, percaya diri, ketekunan dan kebiasaan untuk selalu berfikir.

Sistem pembinaan SD berdasarkan pada pembinaan gugus sekolah yaitu SD sebagai pusat kegiatan pembinaan. Sistem pembinaan SD berdasarkan pada pembinaan gugus yaitu SD inti sebagai pusat kegiatan pembinaan. Pada tahap awal sampai dengan tahun 2012 telah terbentuk 2.695 klub olahraga SD di seluruh Indonesia. Perkembangan klub olahraga SD ini terus berlanjut hingga pada tahun 2014 ada penambahan 1.415 klub olahraga SD di 33 provinsi seluruh Indonesia, sehingga seluruhnya ada 4.110 klub olahraga SD yang telah terbentuk (Petunjuk Teknis O2SN - IX SD, 2016: 1).

Sebagai tolok ukur keberhasilan pembinaan dan pengembangan olahraga di SD tersebut diadakan kegiatan dalam bentuk lomba/pertandingan yang kompetitif sebagai upaya untuk menumbuhkan motivasi dan kecintaan terhadap olahraga sedini mungkin. Kegiatan yang di maksudkan adalah berupa Olimpiade Olahraga Siswa Nasional (O2SN) Sekolah Dasar. O2SN adalah sebuah event nasional untuk menemukan bibit-bibit baru Indonesia dalam bidang olahraga. Event olahraga yang paling bergengsi memliki tahap seleksi peserta yang panjang. Di mulai dari tingkat Kabupaten/ Kota, Provinsi, dan akhirnya atlet-atlet muda Indonesia yang terpilih mewakili Provinsinya masing-masing akan bertarung di tingkat Nasional untuk merebutkan medali dan yang berhasil memperoleh medali akan berpeluang besar untuk menjadi wakil Indonesia untuk mengikuti olimpiade olahraga internasional serta event-event olahraga lainnya.

Bola voli merupakan olahraga prestasi yang membutuhkan kebugaran jasmani yang mampu mendukung pelaksanaan keterampilan dasar dalam permainan. Kondisi fisik merupakan kemampuan dasar yang harus dimiliki setiap atlet dalam permainan bola voli. Dalam kondisi fisik terdapat beberapa komponen. Tangkudung (2012) mengemukakan, komponen-komponen biomotorik dasar antara lain: (1) kekuatan, (2) daya tahan, (3) kecepatan, (4) kelentukan, dan (5) koordinasi. Hal ini merupakan modal untuk peningkatan kemampuan dalam melakukan teknik pukulan 
dalam permainan bola voli. Unsur penunjang lainnya kekuatan adalah komponen yang sangat penting guna meningkatkan kondisi fisik seseorang secara keseluruhan kekuatan dapat di rinci menjadi tiga bentuk yaitu: (1) kekuatan maksimum, (2) kekuatan elastis, dan (3) daya tahan kekuatan.

Keberhasilan dalam mencetak prestasi dalam permainan bola voli sangat dipengaruhi oleh keterampilan dasar dalam permainan bola voli tersebut. Oleh karena itu, pengembangan kemampuan dalam keterampilan dasar permainan bola voli mutlak diperlukan sehingga siswa mampu dengan baik melakukan berbagai keterampilan dasar tersebut. Keberhasilan pengembangan kemampuan siswa tersebut sangat tergantung kepada kemampuan guru atau pelatih dalam melakukan evaluasi terhadap berbagai faktor yang memiliki kontribusi terhadap peningkatan kemampuan siswa dalam melakukan keterampilan dasar bermain bola voli. Berdasarkan pengamatan peneliti di lapangan selama ini, faktor-faktor yang memiliki kontribusi terhadap kemampuan siswa melakukan keterampilan dasar pemainan bola voli antara lain yaitu faktor minat, motivasi. Selain itu media juga mempunyai peranan yang sangat penting dalam pembelajaran teknik dasar passing bawah permainan bola voli.

Penggunaan media pembelajaran di masa COVID-19 ini diharapkan dapat memudahkan siswa untuk tetap bersemangat belajar di rumah, walaupun tidak bertatap muka. Guru dituntut untuk lebih kreatif mengemas pembelajaran dengan baik. Salah satunya dalam pembelajaran bola voli ini. Peneliti ingin berkreasi dan berinovasi dengan mengganti bola voli yang biasa digunakan untuk pembelajaran di sekolah menjadi beberapa alat sederhana yang lebih mudah ditemui oleh siswa dan siswa dapat belajar dengan baik di rumah. Berdasarkan latar belakang tersebut maka peneliti memfokuskan untuk meneliti tentang: "Modifikasi Media Teknik Dasar Passing Bawah Permainan Bola Voli Melalui Video Tutorial bagi Siswa SD Negeri 190 Tanjung Jabung Barat”.

\section{METODE PENELITIAN}

Penelitian ini dilaksanakan di SD Negeri 190 Tanjung Jabung Barat kecamatan Tungkal Ilir Kabupaten Tanjung Jabung Barat Provinsi Jambi. Waktu penelitian yaitu di semester genap tahun ajaran 2019/2020.

Metode penelitian ini yaitu metode penelitian deskriptif kualitatif. Menurut Nawawi (1996) penelitian deskriptif kualitatif adalah penelitian yang menggambarkan atau melukiskan objek penelitian berdasarkan fakta-fakta yang tampak atau sebagaimana adanya.

Subjek pada penelitian ini yaitu siswa kelas 5 SD Negeri 190 Tanjung Jabung Barat yang berjumlah 35 siswa.

Pengumpulan data dalam penelitian ini menggunakan instrumen non-tes yaitu angket/kuesioner. Menurut Sugiyono (2014) kuesioner merupakan teknik pengumpulan data yang dilakukan dengan cara memberi seperangkat pertanyaan atau pernyataan tertulis kepada responden untuk dijawabnya. Angket yang diberikan berupa pendapat siswa tentang video pembelajaran teknik dasar passing bawah bola voli dengan modifikasi media. Angket ini menggunakan skala Likert dengan model empat pilihan (skala empat).

Dalam teknik analisis data dalam penelitian ini, adalah persentase perolehan tanggapan tentang video yang telah di unggah. Persentase ini akan digunakan sebagai tolak ukur efektivitas video tutorial modifikasi media pembelajaran passing bawah bola voli untuk siswa Sekolah Dasar.

Persentase rata-rata tiap komponen dihitung dengan menggunakan rumus sebagai berikut:

$P=\sum \times 100 \%$ 
$\mathrm{N}$

Dimana :

$\mathrm{P}=$ Persentase skor

$\Sigma=$ Jumlah responden yang memilih

$\bar{N}$ = Jumlah responden keseluruhan

Persentase efektivitas Video tutorial modifikasi media pembelajaran passing bawah bola voli yang diterapkan, sebagai berikut:

Tabel 1. Norma Keefektifan Data

\begin{tabular}{lcc}
\hline No & Persentase & Kategori \\
\hline 1 & $0-30 \%$ & Tidak Efektif \\
\hline 2 & $31 \%-50 \%$ & Cukup Efektif (dengan Syarat) \\
\hline 3 & $51 \%-70 \%$ & Efektif \\
\hline 4 & $71 \%-100 \%$ & Sangat Efektif \\
\hline
\end{tabular}

\section{HASIL PENELITIAN DAN PEMBAHASAN}

Setelah merancang berbagai tahapan untuk pembuatan video tutorial pembelajaran modifikasi teknik passing bawah bola voli, maka selanjutnya peneliti akan mengevaluasi dan menganalisis bagaimana modifikasi teknik dasar passing bawah bola voli melalui video tutorial bagi siswa Sekolah Dasar. Tanggapan yang diberikan oleh siswa Sekolah Dasar adalah menggunakan Google Form. Karena adanya pembatasan atas terjadinya Covid-19 baru-baru ini, menyebabkan penyebaran angket dilakukan secara online.

Berikut merupakan diagram tanggapan siswa pada pernyataan angket:

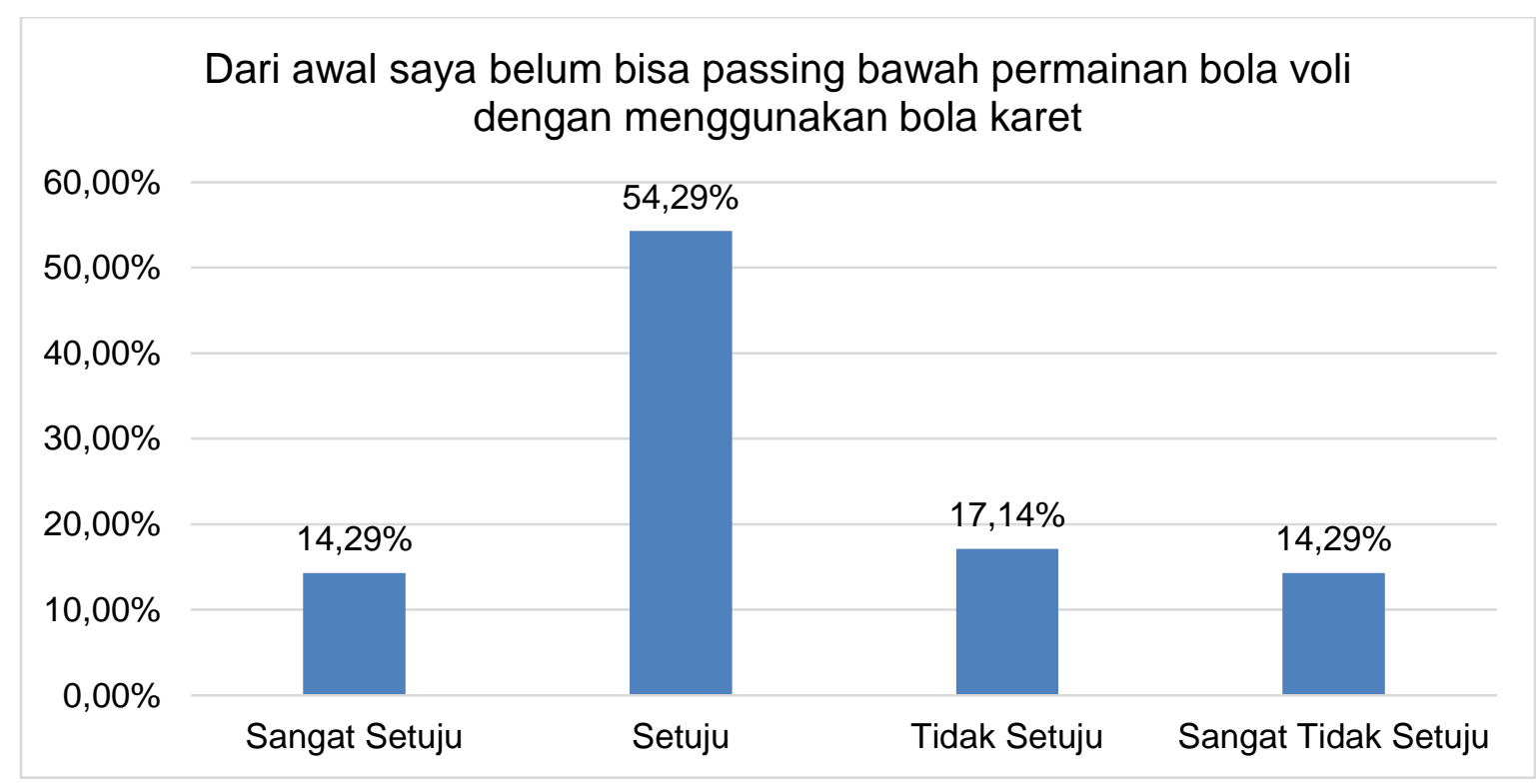

Gambar 1. Diagram pernyataan 3 


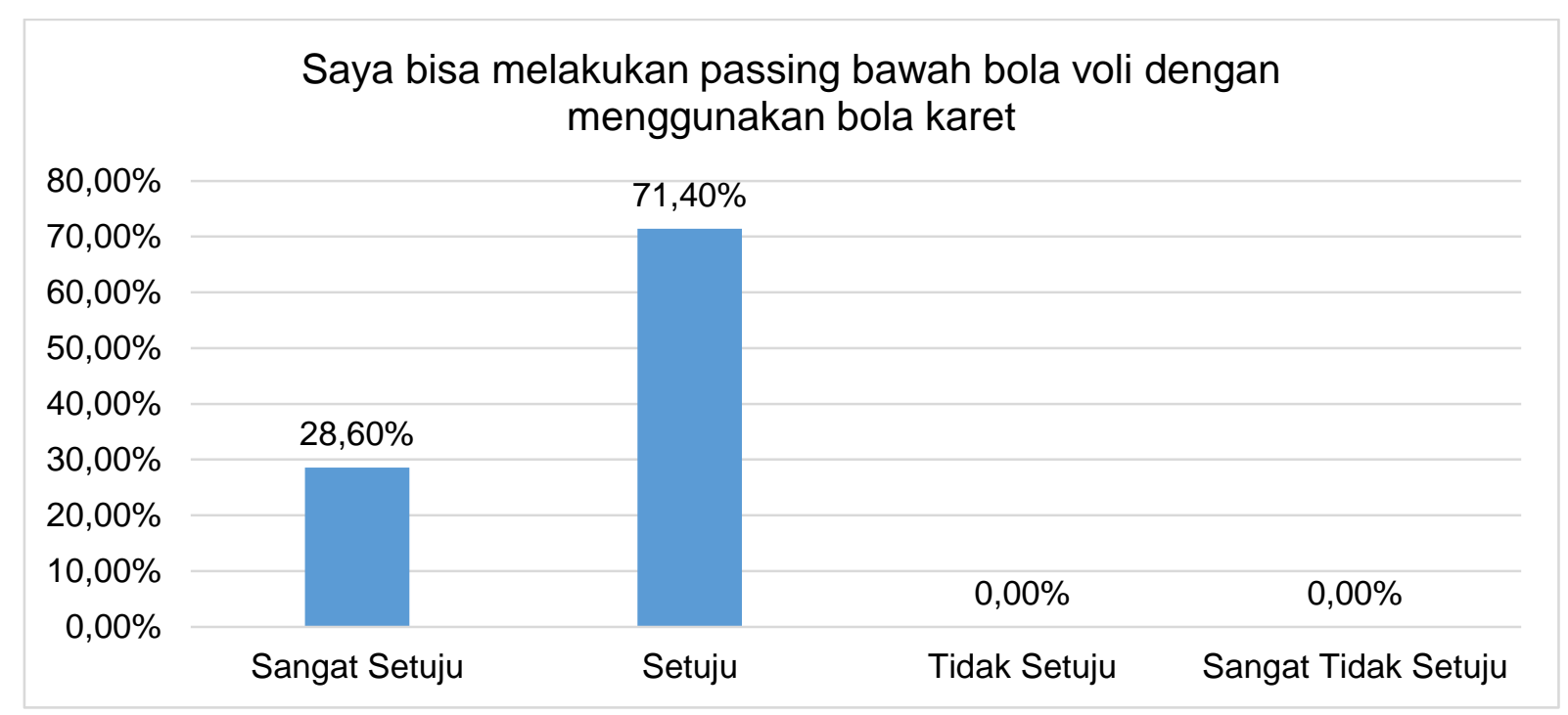

Gambar 2. Diagram pernyataan 15

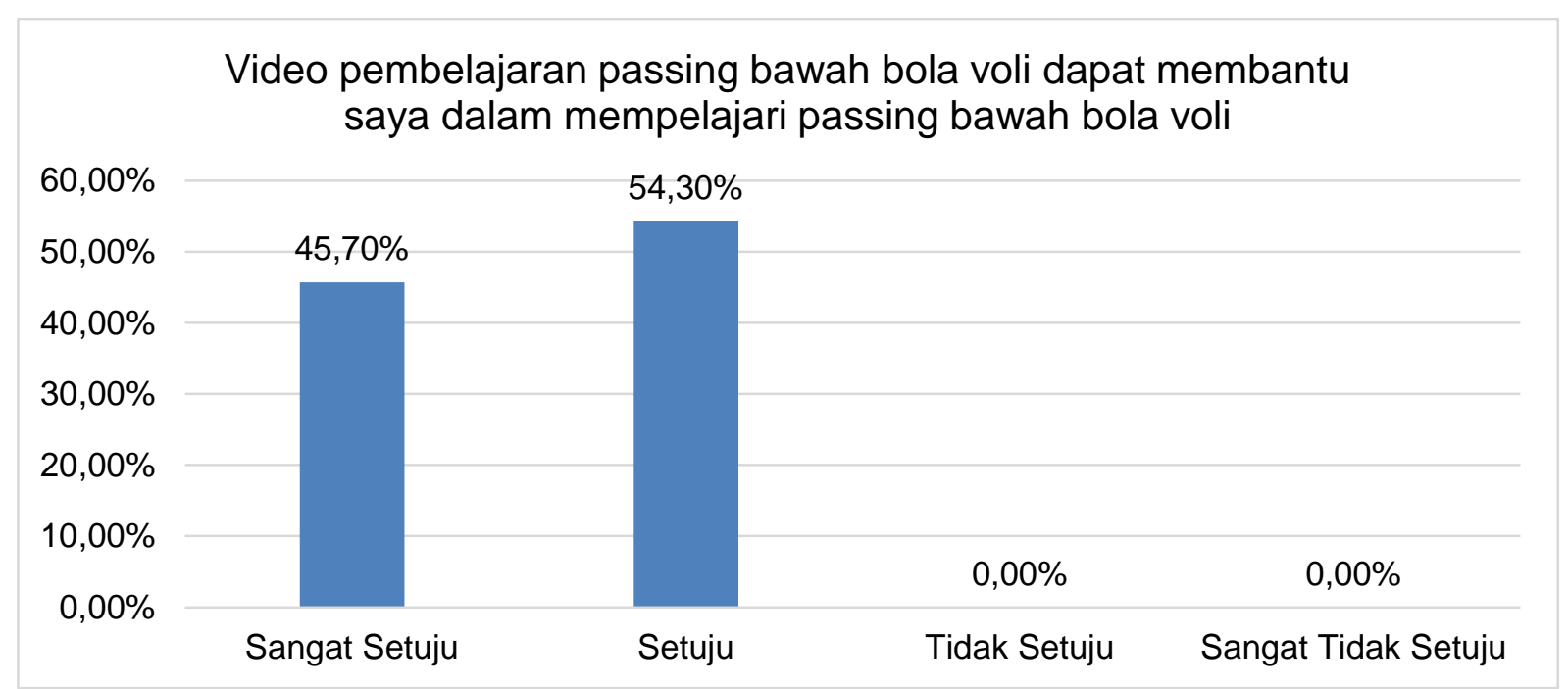

Gambar 3. Diagram pernyataan 27

Berdasarkan dengan video tutorial yang di buat, dan angket/kuesioner yang sudah di tanggapi oleh beberapa responden, di dapat hasil sebagai berikut:

$P=\frac{\sum \times 100 \%}{N}$
$P=\frac{19 \times 100 \%}{35}$
$P=54,30 \%$

Penelitian ini merupakan penelitian yang berfokus pada penggunaan video tutorial tentang modifikasi media pembelajaran teknik passing bawah bola voli untuk siswa Sekolah Dasar. Dalam penelitian ini, peneliti mencoba untuk membuat hal baru dengan menggunakan video tutorial dengan tujuan dapat memberikan kemudahan kepada siswa dalam belajar permainan bola voli.

Dalam video yang dibuat oleh peneliti, peneliti menggunakan modifikasi alat sebagai pengganti bola untuk menyesuaikan permainan bola voli yang akan diterapkan kepada siswa. Bola yang digunakan adalah bola balon, bola karet dan bola voli no. 4 untuk siswa SD.

Didapat hasil bahwa 54,29\% responden mengatakan bahwa belum bisa melakukan passing bawah permainan bola voli dengan menggunakan bola karet. 
Dari pernyataan tersebut, hal inilah yang ditindak lanjuti peneliti untuk membuat video tutorial teknik passing bawah permainan bola voli dengan menggunakan bola karet.

Setelah pembuatan video tutorial dan dilanjutkan dengan menyebarluaskan video tutorial. Berdasarkan Gambar 2 sebanyak 71,04\% responden mengatakan bahwa saya bisa melakukan passing bawah bola voli dengan menggunakan bola karet. Jadi dapat disimpulkan bahwa kemampuan siswa mengalami peningkatan dalam melakukan passing bawah permainan bola voli dengan menggunakan bola karet.

Penggunaan video tutorial sebagai media belajar modifikasi teknik passing bawah bola voli dengan mengubah dan menyederhanakan alat yang digunakan, diharapkan dapat memberikan berbagai efektivitas bagi siswa atau pelaku olahraga untuk dapat berlatih di rumah, walaupun dengan masa Pandemi COVID-19 ini. Virus Corona ini menyebar melalui udara, siswa dilarang untuk datang ke sekolah karena takut tertular virus tersebut, sehingga tahapan dalam penelitian ini, diusahakan untuk tetap sampai kepada siswa, dipraktekkan dengan baik oleh siswa, kemudian siswa memberi tanggapan tentang video tersebut.

Dalam diagram di atas, dapat dilihat bagaimana keefektifan video yang sudah di kembangkan, $54,30 \%$ datri total $100 \%$ responden Setuju bahwa video pembelajaran passing bawah bola boli dapat membantu dalam mempelajari passing bawah bola voli. Dan 45,70\% responden mengatakan Sangat Setuju bahwa video tersebut dapat membantu dalam mempelajari passing bawah bola voli.

Berikut merupakan cara mendapatkan hasil $54,30 \%$ dari total $100 \%$ responden setuju:

$$
\begin{aligned}
& P=\frac{\sum \times 100 \%}{N} \\
& P=\frac{19 \times 100 \%}{35}
\end{aligned}
$$

$P=54,30 \%$

Berdasarkan hasil angket/kuesioner tanggapan siswa, maka di dapat kesimpulan bahwa video tutorial Pembelajaran modifikasi media teknik passing bawah bola voli efektif untuk digunakan.

\section{SIMPULAN}

Berdasarkan penelitian yang telah dilakukan tentang modifikasi media teknik dasar passing bawah permainan bola voli melalui video tutorial bagi siswa sekolah dasar, maka dapat disimpulkan bahwa modifikasi media teknik dasar passing bawah permainan bola voli melalui video tutorial bagi siswa sekolah dasar dapat dilakukan dengan menggunakan bola karet.

Modifikasi teknik dasar passing bawah permainan bola voli melalui video tutorial bagi siswa sekolah dasar dapat diaplikasikan dengan baik (efektif). Video tutorial dapat digunakan sebagai media bantu guru dalam pembelajaran bola voli di sekolah. Penggunaan alat yang di modifikasi diharapkan dapat membantu memudahkan siswa dalam belajar, mengetahui, mampu melakukan, mampu mempraktekkan dan memahami gerakan yang dimaksud oleh peneliti.

\section{RUJUKAN}

Agus, S, Suryoboto. (2001). Diktat Teknologi Pembelajaran Pendidikan Jasmani. Yogyakarta: FIK UNY.

Ahmadi, Nuril. (2007). Panduan Olahraga Bola Voli. Solo: Era Pustaka Utama. 
Amrin, Toyib. (2009). Minat Siswa Kelas X dan XI MAN Gondean Tahun Ajaran 2008/2009 Dalam Mengikuti Pembelajaran Pendidikan Jasmani Olahraga dan Kesehatan. Sripsi. Yogyakarta: FIK UNY.

Anggraini,A., Tomi,A., \& Sulistyorini,S. (2016). Meningkatkan Keterampilan Passing Bawah Menggunakan Latihan Bervariasi Pada Siswa Peserta Ekstrakurikuler Bola Voli SMK Negeri 2 Singosari Kabupaten Malang. Pendidikan Jasmani .ISSN 0853-5043. Vol.26 No.2

Bahagia, Y dan Suherman, A. (2000). Prinsif-prinsif Pengembangan dan Modifikasi Cabang Olahraga. Departemen Pendidikan dan Kebudayaan Direktorat Jendral Pendidikan Dasar dan Menengah Bagian proyek Penataran Guru SLTP Setara D-III.

Barbara L. Viera dan Bonnie Jiil Ferguson. (2004). Bola Voli Tingkat Pemula. Jakarta : Raja Grafindo Persada

Beutelstahl, Dieter. (2007). Belajat Bermain Bola Voli. Bandung: Pionir Jaya

Bootzin, R R. (1975). Behavior Modification and Therapy: An Introduction. Cambridge, Mass, Winthrop Pub

Briggs, Leslie J. (1997). Instructional Design, Educational Technology Ublications Inc. Newjarsey: Englewoodcliffs.

Dinata,Y,N. (2019). Penggunaan Media Pembelajaran Video Tutorial Untuk Meningkatkan Hasil Belajar Siswa Teknik Gambar Bangunan SMKN 1 Seyegan Pada Mata Pelajaran Menggambar Dengan AUTOCAD. ePrints@UNY: Lumbung Pustaka Universitas Negeri Yogyakarta.

Hamalik, Oemar. (2011). Psikologi Belajar Mengajar. Bandung : Sinar Baru.

Jalimah., Haetami,M., \& Triansyah,A. (2017). Peningkatan Hasil Belajar Passing Bawah Bola Voli Dengan Modifikasi Bola Plastik di SDN 33 Simpang Sanurian. Jurnal Pendidikan dan Pembelajaran Khatulistiwa. Vol.6. No.10

Kemp, J. E dan Dayton, D. K. (1995). "Planning and Producing Instructional Media " Cambridge: Harper \& Row plubishers, New York.

Mantri Karno. (2012). Penggunaan Video Tutorial dalam Proses Pembelajarean di SMK. Diakses pada laman https://mantrikarno.wordpress.com /2012/06/08/pengunaan-video-tutorial-dalam-proses-pembelajaran-di-smk-2/ tanggal. 30 Juni 2020

Roji. (1989). Pendidikan Jasmani 2. Jakarta: Intan Pariwara.

Rusli Lutan. (2002). Strategi Mengajar Pendidikan Jasmani. Jakarta : Depdiknas.

Slameto. (2010). Belajar dan Faktor-Faktor yang Mempengaruhi. Jakarta : Rineka Cipta.

Sugiono. (2009). Metode Penelitian Kuantitatif, Kualitatif dan R \& D. Bandung: Alfabeta.

Suharno, H. P. (1981). IImu Coacing umum. IKIP Yogyakarta. Yogyakarta.

Dasar, S., Ekawarna, E., Rahayu, F. D., \& Yuliawan, E. Upaya Meningkatkan Hasil Belajar Smash Bola Voli Siswa Kelas X SMK Negeri 5 Tanjab Barat Melalui Pendekatan Gaya Mengajar Latihan Power Tungkai Dengan Menggunakan Modifikasi Bola Gantung. JURNAL PRESTASI, 5(2), 44-51.

Sukmadinata, Nana Syaodah. (2008). Metode Penelitian Pendidikan. Bandung: PT Remaja Rosda Karya.

Nugraha, U., \& Yuliawan, E. (2021). Meningkatkan hasil belajar passing atas bola voli melalui pendekatan gaya mengajar latihan dengan menggunakan audio visual. Altius: Jurnal Ilmu Olahraga dan Kesehatan, 10(2), 231-242.

Wolpe, J. (1973). The practice of Behavior Therapy, New York, Pergamon Pres. 